\title{
Proximal interphalangeal arthroscintigraphy in rheumatoid arthritis
}

\author{
J. REMANS, H. BERGHS, L. DRIESKENS, L. KIEBOOMS, \\ AND J. POLDERMAN
}

From the Centre of Rheumatology and the Department of Nuclear Medicine, Genk, Belgium

SUMMARY Quantitative scintigraphy of proximal interphalangeal joints was performed by
reproducible method using $99 \mathrm{~m}$-Technetium in the hands of 40 normal controls and 20 patients witis
rheumatoid arthritis (RA). The range of the mean uptake varied considerably between proximaf
interphalangeal (PIP) joints in normal subjects. The mean uptake over PIP joints was not signi
ficantly different either between normal controls and RA patients, nor between those rheumatoids
arthritis patients with and those without clinical signs of inflammation in the PIP joints. However
the variation in the PIP counts was significantly greater in the rheumatoid hands than in the norma
hands. There was no clear correlation between the technetium uptake and the clinical parameters
of inflammation in the PIP joints.

Pain, swelling, and limitation of motion are clinical parameters of inflammatory activity in rheumatoid arthritis, while technetium $\left({ }^{99} \mathrm{~m} \mathrm{Tc}\right)$ scanning is a physical method of measuring inflammation in joints (Dick et al., 1970). The aim of this study was (1) to determine a 'normal range' for PIP joint scanning performed in 'normal controls'. (2) To compare ${ }^{99} \mathrm{Tc}$-pertechnetate PIP joint quantitative scintigraphy in rheumatoid arthritis patients and in normal controls. (3) To compare the inflammatory state of the joints (synovitis) assessed by clinical and scintigraphic methods.

\section{Materials and methods}

\section{CLINICAL}

Forty 'normal controls' and 20 patients with rheumatoid arthritis were submitted to quantitative PIP scintigraphy. The normal controls consisted of healthy persons without any clinical or radiological abnormalities of the hands. Laboratory investigations confirmed the absence of abnormal serological and immune factors, and normal eryrothcyte sedimentation rates and haemoglobin values.

All RA patients had 'classical' or "definite" RA. They belonged to the functional classes II or III and the anatomical stages $I I$ or III according to the ARA criteria. They had suffered from the disease for

Accepted for publication December 12, 1977 more than 2 years and were all receiving therapy Eleven of the RA patients had clinical signs of active inflammation (pain, swelling, tenderness on pa周 pation or motion) in at least one PIP joint. The remaining 9 RA patients had no clinical signs of active inflammation at the PIP level.

\section{ARTHROSCINTIGRA PHY}

The counting apparatus consisted of a sodiun iodide crystal and a photomultiplier system cone nected to a scaler and channel analyser. The entire crystal-photomultiplier system was encased in lead $8 \mathrm{~mm}$ thick, so that the background count rate with the patient in position was reduced to the order of $5 \%$ of that recorded with the finger joint in place.

A good definition of each PIP joint was obtaine by positioning the PIP joint in a lead chamber op the surface of the collimator mounted over the crystal (Sturrock et al., 1974).

Approximately $500 \mu \mathrm{Ci}$ of $99 \mathrm{~m}$-Technetium pertechnetate was injected into the cubital veino The technetium for injection was made up to 2 mb with physiological saline in a $5 \mathrm{ml}$ syringe. This waई fixed over the crystal by an attachment to the collimator for counting the injected dose under theo same conditions as the PIP joints. This allowe $\bar{\Phi}$ accurate calculation of the difference in count $\$$ between the filled syringe before and the empty syringe after the intravenous injection of technetiume Hands were rested for 1 hour before carrying out 
the test. Twenty minutes after injection, PIP joint counts were measured in a standard order from the thumb to the little finger, first in the right hand and then in the left hand. The counting time was $30 \mathrm{~s}$ over each PIP joint. The ${ }^{99} \mathrm{Tc}$ uptake was expressed as a percentage $\left(\% \times 10^{-3}\right)$ of the administered dose.

The reproducibility of the counts on individual PIP joints was of the order of $5 \%$.

\section{Results}

In the 40 normal controls, uptakes for the same finger showed a mean variability as expressed by coefficients of variation from 25 to $27 \%$. The mean value for each finger increased from little finger to thumb on both hands (Table 1).

The analysis of variance (Table 2) shows that the uptake differs significantly for each of the 5 fingers (a) and among the different patients (b).

A significant difference exists in the evolution of the counts from little finger to thumb $(c=$ finger $x$ patient interaction). There is however no significant difference between right and left hand (d) and no significant difference between the two hands in the evolution from little finger to thumb (e). For each finger, using the mean and standard deviations, a tolerance interval is calculated (Table 3 ) giving a tolerance probability of 0.95 and a confidence probability of 0.95 . This tolerance interval is taken as the 'normal range'. (Sokal and Rohlf, 1969).

Comparison (Student's $t$ test) of the 20 normal controls and 40 RA patients (Table 4) shows no significant differences between the mean values of normal controls and of RA patients, though the values of RA patients always lie a little higher. Fig. 1 illustrates the results for the left little finger. It is obvious that the values of many RA patients lie within the normal range.

The variances of the PIP counts are significantly higher ( $F$ variance ratio-Snedecor and Cochran, 1967) in RA patients than in normal controls (Table 4).

Comparing 11 RA patients with and 9 RA patients

Table 1 Count rate $\left(\% \times 10^{-3}\right.$ of injected dose $)$ of each PIP joint in 40 normal controls

\begin{tabular}{|c|c|c|c|c|c|}
\hline & Little finger & Ring finger & Middle finger & Forefinger & Thumb \\
\hline $\begin{array}{l}\text { Right hand } \\
\text { Left hand }\end{array}$ & $\begin{array}{l}2 \cdot 80 \pm 0.73 * \\
(26) \dagger \\
2 \cdot 73 \pm 0.69 \\
(25)\end{array}$ & $\begin{array}{l}3.10 \pm 0.83 \\
(27) \\
3.08 \pm 0.83 \\
(27)\end{array}$ & $\begin{array}{l}3.41 \pm 0.90 \\
(26) \\
3 \cdot 36 \pm 0.90 \\
(27)\end{array}$ & $\begin{array}{l}3.51 \pm 0.93 \\
(26) \\
3 \cdot 51 \pm 0.90 \\
(26)\end{array}$ & $\begin{array}{l}4 \cdot 54 \pm 1 \cdot 19 \\
(26) \\
4 \cdot 54 \pm 1 \cdot 13 \\
(25)\end{array}$ \\
\hline
\end{tabular}

$*$ Mean \pm SD

†Coefficient of variation.

Table 2 Three-way analysis of variance on the counts of the PIP joints in 40 normal controls

\begin{tabular}{|c|c|c|c|c|c|c|}
\hline \multicolumn{2}{|c|}{ Source of variation } & \multirow{2}{*}{$\begin{array}{l}\text { Degree of } \\
\text { freedom }\end{array}$} & \multirow{2}{*}{$\begin{array}{l}\text { Sum of squares } \\
143 \cdot 451\end{array}$} & \multirow{2}{*}{$\begin{array}{l}\text { Mean square } \\
35 \cdot 863\end{array}$} & \multirow{2}{*}{$\begin{array}{l}\text { Variance ratio } \\
\text { (with indication of } \\
\text { the sum of squares } \\
\text { used) } \\
\text { a/g }=199\end{array}$} & \multirow{2}{*}{$\begin{array}{l}\text { Significance } \\
\mathrm{P}<10^{-50}\end{array}$} \\
\hline (a) & Between fingers & & & & & \\
\hline (b) & Between patients & 39 & $285 \cdot 352$ & $7 \cdot 317$ & $d / g=143$ & $P<10^{-10}$ \\
\hline (c) & Finger $\times$ patient interaction & 156 & 28.046 & $0 \cdot 180$ & $\mathrm{e} / \mathrm{g}=3 \cdot 53$ & $P<10^{-10}$ \\
\hline (d) & Between hands & 1 & 0.064 & 0.643 & $\mathrm{~b} / \mathbf{f}=<\mathbf{1}$ & NS \\
\hline (f) & Hand $\times$ patient interaction & 39 & $5 \cdot 711$ & $0 \cdot 146$ & $f / g=2 \cdot 86$ & $P<10^{-5}$ \\
\hline (g) & $\begin{array}{l}\text { Residual interaction } \\
\text { (finger } \times \text { hand } \times \text { patient) }\end{array}$ & 156 & 7.906 & 0.051 & & \\
\hline (h) & Total & 399 & $470 \cdot 626$ & & & \\
\hline
\end{tabular}

NS $=$ not significant.

Table 3 Tolerance* interval for the counts $\left(\% \times 10^{-3}\right)$ of each normal PIP joints

\begin{tabular}{|c|c|c|c|c|c|}
\hline & Little finger & Ring finger & Middle finger & Forefinger & Thumb \\
\hline $\begin{array}{l}\text { Right hand } \\
\text { Left hand }\end{array}$ & $\begin{array}{l}1 \cdot 00-4 \cdot 60 \\
1 \cdot 05-4 \cdot 40\end{array}$ & $\begin{array}{l}1 \cdot 06-5 \cdot 14 \\
1 \cdot 06-5 \cdot 10\end{array}$ & $\begin{array}{l}1 \cdot 20-5 \cdot 61 \\
1 \cdot 16-5 \cdot 56\end{array}$ & $\begin{array}{l}1 \cdot 22-5 \cdot 78 \\
1 \cdot 30-5 \cdot 72\end{array}$ & $\begin{array}{l}1 \cdot 63-7 \cdot 44 \\
1 \cdot 76-7 \cdot 32\end{array}$ \\
\hline
\end{tabular}

* Tolerance probability $=0.95$. Confidence probability $=0.95$. 
Table 4 Counts $\left(\% \times 10^{-3}\right)$ of each PIP joint (mean $\left.\pm S D\right)$. Comparison of 40 normal controls and 20 RA patien

\begin{tabular}{|c|c|c|c|c|c|c|c|c|c|c|}
\hline & \multicolumn{5}{|c|}{ Right hand } & \multicolumn{5}{|c|}{ Left hand } \\
\hline & $\begin{array}{l}\text { Little } \\
\text { finger }\end{array}$ & $\begin{array}{l}\text { Ring } \\
\text { finger }\end{array}$ & $\begin{array}{l}\text { Middle } \\
\text { finger }\end{array}$ & $\begin{array}{l}\text { Fore- } \\
\text { finger }\end{array}$ & Thumb & Thumb & $\begin{array}{l}\text { Fore- } \\
\text { finger }\end{array}$ & $\begin{array}{l}\text { Middle } \\
\text { finger }\end{array}$ & $\begin{array}{l}\text { Ring } \\
\text { finger }\end{array}$ & $\begin{array}{l}\text { Little } \overrightarrow{\overline{0}} \\
\text { finger }\end{array}$ \\
\hline $\begin{array}{l}\text { Controls }(n=40) \\
\text { RA patients }(n=20)\end{array}$ & $\begin{array}{r}2 \cdot 80 \pm \\
0.73 \\
2 \cdot 87 \pm \\
1 \cdot 27\end{array}$ & $\begin{array}{r}3 \cdot 10 \pm \\
0 \cdot 83 \\
3 \cdot 68 \pm \\
1 \cdot 89\end{array}$ & $\begin{array}{r}3.41 \pm \\
0.90 \\
3 \cdot 96 \pm \\
1.93\end{array}$ & $\begin{array}{r}3 \cdot 51 \pm \\
0.93 \\
4 \cdot 28 \pm \\
2 \cdot 04\end{array}$ & $\begin{array}{r}4 \cdot 54 \pm \\
1 \cdot 19 \\
4 \cdot 59 \pm \\
2 \cdot 07\end{array}$ & $\begin{array}{r}4 \cdot 54 \pm \\
1 \cdot 13 \\
4 \cdot 49 \pm \\
1.92\end{array}$ & $\begin{array}{r}3 \cdot 51 \pm \\
0 \cdot 90 \\
3 \cdot 73 \pm \\
1 \cdot 80\end{array}$ & $\begin{array}{r}3 \cdot 36 \pm \\
0 \cdot 90 \\
3 \cdot 92 \pm \\
2 \cdot 18\end{array}$ & $\begin{array}{r}3 \cdot 08 \pm \\
0 \cdot 83 \\
3 \cdot 59 \pm \\
2 \cdot 07\end{array}$ & 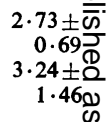 \\
\hline $\begin{array}{l}\text { Student's two sample } t \text { test: mean difference } \\
\mathbf{P}\end{array}$ & $\begin{array}{l}0 \cdot 22 \\
\text { NS }\end{array}$ & $\begin{array}{l}1 \cdot 31 \\
\text { NS }\end{array}$ & $\begin{array}{l}1 \cdot 21 \\
\text { NS }\end{array}$ & $\begin{array}{l}1.60 \\
\text { NS }\end{array}$ & $\begin{array}{l}0 \cdot 10 \\
\text { NS }\end{array}$ & $\begin{array}{l}-0 \cdot 10 \\
\text { NS }\end{array}$ & $\begin{array}{l}0.51 \\
\text { NS }\end{array}$ & $\begin{array}{l}1 \cdot 10 \\
\text { NS }\end{array}$ & $\begin{array}{l}1.06 \\
\text { NS }\end{array}$ & $\begin{array}{l}1.48 \\
\text { NS }\end{array}$ \\
\hline $\begin{array}{l}\text { Snedecor's } \mathbf{F} \text { variance ratio } \\
\mathbf{P}\end{array}$ & $\begin{array}{l}3.02 \\
<0.01\end{array}$ & $\begin{array}{l}5 \cdot 18 \\
<0.01\end{array}$ & $\begin{array}{l}4.59 \\
<0.01\end{array}$ & $\begin{array}{l}4.81 \\
<0.01\end{array}$ & $\begin{array}{l}3.02 \\
<0.01\end{array}$ & $\begin{array}{l}2 \cdot 88 \\
<0 \cdot 01\end{array}$ & $\begin{array}{l}4.00 \\
<0.01\end{array}$ & $\begin{array}{l}5 \cdot 86 \\
<0.01\end{array}$ & $\begin{array}{l}6 \cdot 21 \\
<0.01\end{array}$ & $\begin{array}{l}4.47 \\
<0.01\end{array}$ \\
\hline
\end{tabular}

without clinical signs of inflammation in at least one PIP joint (Table 5), there is no significant difference between the mean values (Student's $t$ test) nor between the variances ( $F$ variance ratio) of the counts.

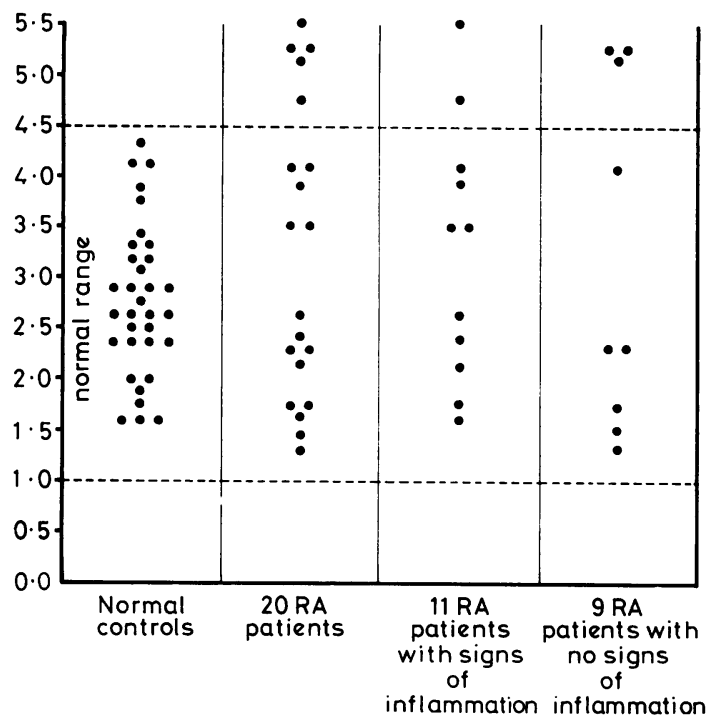

Fig. 1 Count $\left(\% \times 10^{-3}\right.$ of injected dose $)$ for one PIP joint. Example of a left finger.
Both clinical inflammatory signs and abnormal scanning results tend to cluster in some patients The fingers are not involved at random.

Table 6 shows the number of affected fingers pet patient. These results preclude performing the cos cordance studies on a joint basis and suggest working on a patient basis: patients with at least one joig involved versus patients with no joint involved.

The cross-matching of the scan results and thents clinical state of the $20 \mathrm{RA}$ patients is presented in Table 7. The cells with concordant results are show in bold. For the scintigraphic results, the specificity (Feinstein, 1974) is $4 / 8=0.50$; the sensitivi is $5 / 8=0.63$; the validity $(4+5) / 20=0.45$; the coefficient of association $(4 \times 5-4 \times 7) /(4 \times 5$ 年 $4 \times 7)=-0 \cdot 16$

In these $20 \mathrm{RA}$ patients there is no relationsh between the scan results and the clinical signs active inflammation (Fisher's exact probability test) is not significant.

\section{Discussion}

This method of quantitative scintigraphy achieves satisfactory reproducibility (of the order of $5 \%$ ) for the PIP joints of the hands. The scanning mea between normal controls and rheumatoid arthritis

Table 5 Counts $\left(\% \times 10^{-3}\right)$ of each PIP joint (mean $\left.\pm S D\right)$. Comparison of 11 RA patients with clinical signs inflammation in at least one PIP joint and $9 R A$ patients with no signs of inflammation

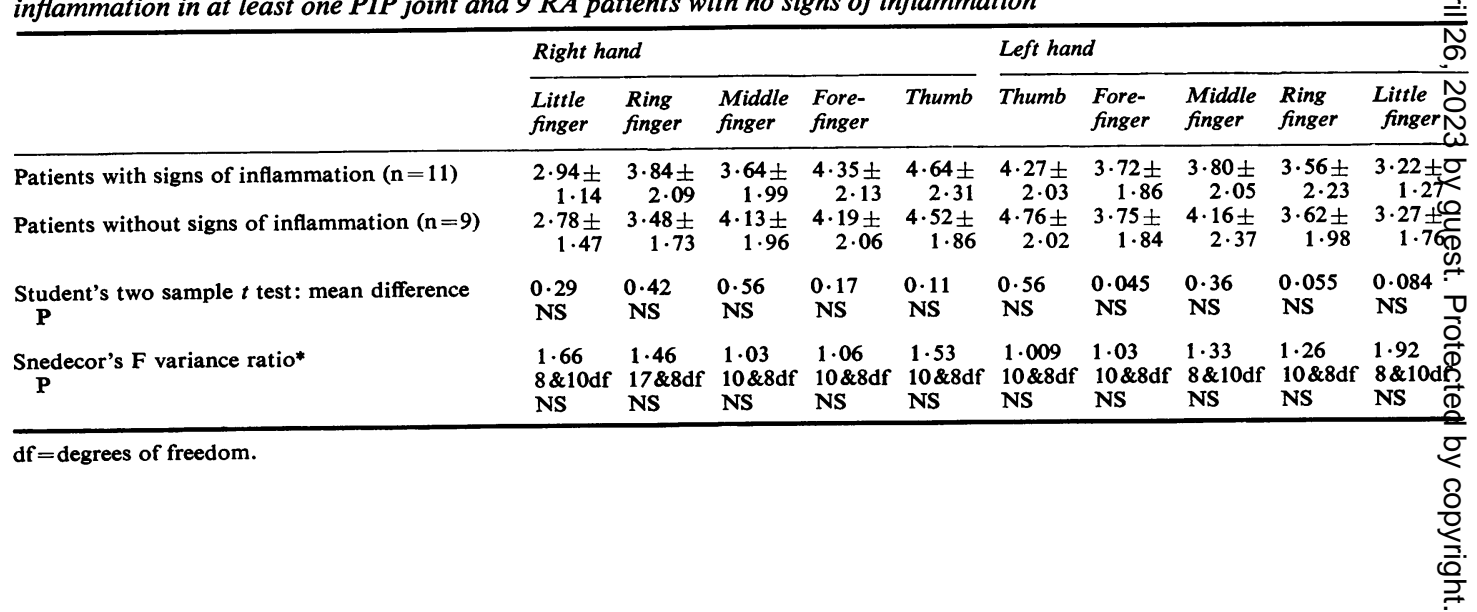


Table 6 Number of fingers involved per patient

\begin{tabular}{|c|c|c|c|}
\hline $\begin{array}{l}\text { No. of fingers } \\
\text { involved (r) }\end{array}$ & $\begin{array}{l}\text { Frequency of } \\
\text { patients with } \\
\mathrm{r} \text { fingers } \\
\text { showing clinical } \\
\text { signs of } \\
\text { inflammation }\end{array}$ & $\begin{array}{l}\text { Frequency of } \\
\text { patients with } \\
\mathrm{r} \text { fingers } \\
\text { with elevated } \\
\text { scanning- } \\
\text { counts }\end{array}$ & $\begin{array}{l}\text { Frequency of } \\
\text { patients with } \\
\mathrm{r} \text { fingers } \\
\text { with elevated } \\
\text { scanning- } \\
\text { counts and with } \\
\text { clinical signs of } \\
\text { inflammation }\end{array}$ \\
\hline 0 & 9 & 12 & 16 \\
\hline 1 & 5 & 0 & 2 \\
\hline 2 & 2 & 2 & 0 \\
\hline 3 & 0 & 0 & 0 \\
\hline 4 & 1 & 2 & 1 \\
\hline 5 & 1 & 1 & 1 \\
\hline 6 & 2 & 1 & 0 \\
\hline 7 & 0 & 0 & 0 \\
\hline 8 & 0 & 1 & 0 \\
\hline 9 & 0 & 0 & 0 \\
\hline 10 & 0 & 1 & 0 \\
\hline $\begin{array}{l}\text { Mean } \\
\text { Variance }\end{array}$ & $\begin{array}{l}1 \cdot 50 \\
4 \cdot 26\end{array}$ & $\begin{array}{l}2.05 \\
9.52\end{array}$ & $\begin{array}{l}0.55 \\
1.94\end{array}$ \\
\hline$q=\frac{\text { variance }}{\text { mean }}$ & $2 \cdot 17$ & $4 \cdot 65$ & 3.53 \\
\hline $\begin{array}{l}\text { Positive } \\
\text { binomial } \\
\text { distribution }\end{array}$ & $\begin{array}{l}\text { Rejected since } \\
9>1\end{array}$ & $\begin{array}{l}\text { Rejected since } \\
9>1\end{array}$ & $\begin{array}{l}\text { Rejected since } \\
9>1\end{array}$ \\
\hline $\begin{array}{l}\text { Poisson } \\
\text { distribution }\end{array}$ & $\begin{array}{l}\text { Rejected since } \\
9>1 \text { and by a } \\
\text { test for Poisson } \\
\text { series }\end{array}$ & $\begin{array}{l}\text { Rejected since } \\
9>1 \text { and by a } \\
\text { test for Poisson } \\
\text { series }\end{array}$ & $\begin{array}{l}\text { Rejected since } \\
9>1 \text { and by a } \\
\text { test for Poisson } \\
\text { series }\end{array}$ \\
\hline
\end{tabular}

Table 7 Concordance between scan results and clinical state of joints in 20 RA patients

\begin{tabular}{llll}
\hline Clinical state & \multicolumn{2}{l}{ Scan results } & \\
\cline { 2 - 3 } & $\begin{array}{l}\text { Too high } \\
\text { once }\end{array}$ & $\begin{array}{l}\text { Always within } \\
\text { norms }\end{array}$ & $\begin{array}{l}\text { Total } \\
\text { clinical state }\end{array}$ \\
\hline $\begin{array}{c}\text { At least one PIP } \\
\text { joint with } \\
\text { inflammation }\end{array}$ & 4 & 7 & 11 \\
$\begin{array}{c}\text { No PIP joint with } \\
\text { inflammation }\end{array}$ & 4 & 5 & 9 \\
$\begin{array}{c}\text { Total scan results } \\
\text { Totan }\end{array}$ & 8 & 12 & 20 \\
\hline
\end{tabular}

patients are not significantly different. This can be attributed to the overlap of numerous RA values within the 'normal range'. The significant difference between the variances of these 2 groups adds some weight to this assumption.

Regarding the inflammation assessed by clinical methods or by scintigraphy, the fingers are not affected by RA at random. Clusters of involved fingers exist in some patients. For our 20 RA patients, the scan results and the clinical signs of joint inflammation are not related. Dick et al., (1970), Green and Hays (1972), and Weiss and Schuler (1974) found that technetium uptake over rheumatoid joints correlated with disease activity, though these workers demonstrated also that the joint scans could be positive when clinical examination is unremarkable; the reverse situation was less frequent. Huskisson et al. (1973) have reported that in an individual joint with arthritis, the ${ }^{99 \mathrm{~m}} \mathrm{Tc}$ uptake correlated neither with the clinical inflammatory signs nor with the thermography of the same joint.

Using a quantitative method, we observed (Remans et al., 1976) no significant correlation between the clinical evolution and the scanning evolution of rheumatoid hand joints under treatment with an anti-inflammatory drug.

This lack of correlation could be explained by the hypothesis that radioisotope assessment measures something related to, but not identical with, the clinical parameters of rheumatoid synovitis.

\section{References}

Dick, W. C., Neufeld, R. R., Prentice, A. G., et al. (1970). Measurement of joint inflammation. A radioisotopic method. Annals of the Rheumatic Diseases, 29, 135-137.

Green, F. A., and Hays, M. T. (1972). The pertechnetate joint scan. II. Clinical correlations. Annals of the Rheumatic Diseases, 31, 278-281.

Feinstein, A. R. (1974). Clinical biostatistics XXXI: On the sensitivity, specificity and discrimination of diagnostic tests. Clinical Pharmacology Therapeutics, 17, 104-115.

Huskisson, E. C., Berry, H., Browett, J. P., and Wykeham Dalme, H. (1973) Measurement of inflammation Part II: Comparison of Technetium clearance and thermography with standard methods in a clinical trial. Annals of the Rheumatic Diseases, 32, 99-102.

Remans, J., Berghs, H., Drieskens, L., Kiebooms, L., and Polderman, J. (1976). Scintiscan evaluation of rheumatoid hands for monitoring the anti-inflammatory effects of drugs. Journal Belge de Rhumatologie et de Médecine Physique, 31, 211-218.

Snedecor, G. W., and Cochran, W. G. (1967). Analysis of independent samples when $\mathrm{O}^{1} \mid \mathrm{O}^{2}$. In Statistical Methods, 6th Edition, pp. 114-116. Iowa State University Press USA.

Sokal, R. R., and Rohlf, F. J. (1969). Graphic test for normality - Rankit method for small samples. In Biometrythe Principles and Practice of Statistics in Biological Research, p. 124. Freeman: San Francisco.

Sturrock, R. D., Nicholson, R. and Wojtulewski, J. A. (1974). Technetium counting in rheumatoid arthritis. Evaluation in the small joints of the hands. Arthritis and Rheumatism, $17,417-420$.

Weiss, T. E., and Schuler, S. E. (1974). Joint imaging as a clinical aid in diagnosis and therapy of arthritic and related diseases. Bulletin on the Rheumatic Diseases, 25, 791-793. 